\title{
Actividades basadas en videos para comprender coloquialismos transmitidos en comedias de situación entre adolescentes
}

Video based activities for understanding colloquialisms broadcasted in sitcoms among teenagers

1 Víctor Hugo López Salazar https://orcid.org/ 0000-0002-1377-1790 Pontificia Universidad Católica del Ecuador Sede Ambato, Facultad de Ciencias de la Educación Ambato-Ecuador victor.h.lopez.s@pucesa.edu.ec

2 Elsie Ileana Vásquez Soria Pontificia Universidad Católica del Ecuador Sede Ambato, Facultad de Ciencias de la Educación Ambato-Ecuador evasquez@pucesa.edu.ec

\section{Cítese: López Salazar, V. H., \& Vásquez Soria, E. I. (2022). Actividades basadas en videos para comprender coloquialismos transmitidos en comedias de situación entre adolescentes. Ciencia Digital, 6(1), 71-90. https://doi.org/10.33262/cienciadigital.v6i1.1955}

CIENCIA DIGITAL, es una Revista multidisciplinaria, Trimestral, que se publicará en soporte electrónico tiene como misión contribuir a la formación de profesionales competentes con visión humanística y crítica que sean capaces de exponer sus resultados investigativos y científicos en la misma medida que se promueva mediante su intervención cambios positivos en la sociedad. https://cienciadigital.org

La revista es editada por la Editorial Ciencia Digital (Editorial de prestigio registrada en la Cámara Ecuatoriana de Libro con No de Afiliación 663) www.celibro.org.ec 
Palabras

claves:

actividades

basades

en

vídeos,

coloquialismos, comedias, entendimiento, pragmática, educación.

\section{Keywords:}

video-based activities, colloquialisms, sitcoms, understanding, pragmatics, education.

\section{Resumen}

Introducción. La implementación de actividades basadas en videos para la enseñanza de idiomas ha contribuido positivamente a impulsar la comprensión del inglés como lengua extranjera a través de una pedagogía interactiva para entender el lenguaje coloquial y la pragmática en las comedias de situación. Objetivo. Este estudio tiene como objetivo analizar actividades basadas en videos para comprender los coloquialismos estadounidenses sobre comedias de situación. Metodología. Al emplear un marco de investigación cuasi - experimental con énfasis en el enfoque cuantitativo, este estudio evaluó la comprensión del lenguaje coloquial entre adolescentes a través de un tratamiento de cuatro semanas utilizando actividades de video integradas en diferentes plataformas. Resultados. Los resultados de la comparación entre la prueba previa y la prueba posterior para ambos grupos demostraron una diferencia considerable. Los principales hallazgos se detallan a continuación; Por un lado, las puntuaciones sin intervención en ambos grupos muestran $(\mathrm{M}=-0,640, \mathrm{EE}=1,063$, valor de $\mathrm{p}=0,553)$. Por otra parte, las puntuaciones después de aplicar el tratamiento de cuatro semanas demuestran resultados significativos entre ambos grupos puntuaciones post test determinado de la siguiente manera $(\mathrm{M}=8.000, \mathrm{SE}=0.542$, valor de $\mathrm{p}=<.001)$. Conclusión. Está comprobado que la introducción de actividades basadas en videos para entender coloquialismos en las aulas de Lengua Extranjera de inglés (EFL) constituye una tendencia de enseñanza dinámica y comprometida debido a la accesibilidad para introducir materiales auténticos y apoyar el proceso de aprendizaje con ayudas visuales.

\section{Abstract}

Introduction. The implementation of video-based activities for teaching languages has contributed positively to boost understanding English as a foreign language through an interactive pedagogy to understand colloquial language and pragmatics on sitcoms. Objective. This study is aimed at analyzing video-based activities for comprehending American colloquialisms on sitcoms. Methodology. By employing a quasi-experimental research framework with emphasis on quantitative approach, this study evaluated the understanding on colloquial language among teenagers through four week treatment using embedded video 
activities in different platforms. Results. Results from the comparison between pretest and posttest for both groups demonstrated a considerable difference. The principal findings are detailed as follows; on the one hand, the scores without intervention in both groups shows $(\mathrm{M}=-0.640, \mathrm{SE}=1.063$, $\mathrm{p}$-value= 0,553). On the other hand, the scores after applying four week treatment demonstrates significant outcomes between both groups' posttest scores determined as follows $(\mathrm{M}=8.000, \mathrm{SE}=0.542, \mathrm{p}$-value $=<$ $.001)$. Conclusion. It is proved that, introducing video-based activities to understand colloquialisms in English Foreign Language (EFL) classrooms constitutes a dynamic and engaged teaching trends due to the accessibility to introduce authentic materials and support the learning process with visual aids.

\section{Introduction}

The application of Internet on education has renewed the process of teaching and opened an ample opportunity to master languages in a totally dissimilar learning atmosphere. For instance, watching movies, cartoons, TV shows, lectures and all authentic videos benefit L2 learners to develop proficiency in the language (Metruk, 2018). In the last years, technology has bombarded the world with limitless information for different purposes as set out entertainment and instruction (Bahrani \& Sim, 2012). Plonsky \& Ziegler (2016) state that Computer Assisted Language Learning (CALL) is crucial to provide the most suitable resources to enhance language learning development. Indeed, video-based learning has multiple facets that allow learners to explore in detail what results completely difficult to understand by texts or inanimate photos (Yousef et al., 2014).

In EFL classrooms worldwide, the understanding of English colloquialisms spoken in real-life conversations have evidently been a setback for learners who want to go beyond the classroom to establish a talk with native speakers or comprehend episodes of their favorite American sitcoms. Unfortunately, most learners have been taught with inadequate approaches, strategies and techniques under traditional book tasks resulting in misinterpretation of colloquialisms found in spoken settings by native speakers. The implementation of videos in English Foreign Language in south America (EFL) demonstrates that technology has become a priority in EFL class due to the fact that videos can transform lessons into a dynamic process which improves learning experience by means of exposure to the target language as well as learning from the real language cultural context (Sunubi \& Utary, 2020). 
According to Bajrami \& Ismaili (2016), using authentic video resources inside and outside the EFL classroom show a high impact on students' acquisition of language. This process also constitutes an advancement for both teachers and learners in terms of meaningful learning. The use of technology in education contributes simultaneously to capture students' attention towards learning and prepare themselves to get familiar with the use and application of digital tools (Bravo et al., 2011). Considering current statistics, Ecuador is not far from this reality where solely grammar-based resources are included in EFL classrooms to complete school curricula units. Additionally, monotonous activities to develop the lessons directly affect the improvement of language competences as well as social skills. The low quality of interactive resources does not contribute to gather high standards in education. The circumstances are not in favor at Eloy Alfaro Educational Unit in Huigra where learners encounter serious difficulties to comprehend English language behind expressions, jokes, and sarcasm commonly spoken on sitcoms.

Consequently, the current study seeks to analyze video-based activities for understanding colloquialism through American sitcoms. In line with it, this paper encompasses a didactic proposal that involves the usage of videos in order to comprehend popular idioms, expressions, slangs, and other features using sitcoms. In addition, it contains activities and illustrative ideas ready to be used in class embracing language skills, pragmatics and cultural awareness integrated in interactive teaching trends. The use of informal language is a multifaceted phenomenon that could be taught from school based on the most demanded situations in life which requires an extensive knowledge on expressions to be used spontaneously (Lima \& Senefonte, 2020). As it can be seen, informal language in daily speech has been catalogued for combining both English interaction and cultural competence (Lee, 2016).

Sun (2016) remarks the importance of authenticity when selecting materials aimed at developing communication in real backgrounds which relies on curricula, class and learner's goals. However, there are not extensive materials designed to work on L2 learner-centered activities based on designed specific video resources to be implemented in the classrooms which evoke an overwhelming time to discern what results appropriate, meaningful, and relevant for learners (Park \& Jung, 2016). Therefore, the current proposal is also underpinned by American sitcoms due to the popularity and accessibility among teenagers. Furthermore, sitcoms provide entertainment and relaxation at the same time which captures student's interests on expanding knowledge of the language since they fit perfectly on what seems to be expected in and out of class (Sun, 2016). Moreover, the literature review conducted in this paper focuses its attention on different studies related to understanding informal language on sitcoms and other audiovisual genres through video-based activities and video clips strengthening even more on the aims why this research justifies a deep analysis. 
The objectives of this research are aimed at analyzing video-based activities for understanding American colloquialisms on sitcoms by means of applying innovative approaches that enable real-life conversation understanding. Moreover, this research will identify factors that evoke misunderstanding of colloquialisms in conversations. In addition to this, a handbook will be created with video-based activities including strategies aimed at comprehension of informal language. Furthermore, results spotted after data interpretation will be illustrated within the educational community. Additionally, this study will be methodologically conducted as follows; the design encompasses primary and secondary research. Besides, it will be quasi-experimental aligned to qualitative-quantitative approaches, and the depth will be settled as descriptive and explanatory analysis as well. It will also involve socio-educational modality and the instruments to carry this research out are survey and pre-posttest throughout a questionnaire.

Regarding the structural composition of this paper, it is organized into an introduction which determines the main problem, two sections that explain the application, suitability, and reliability of authentic videos in EFL classrooms and other that deepen on informal language understanding, a section corresponding to the systematization of results gathered in the process of researching and a discussion on these results, a methodological section to present the didactic proposal and the intervention phase with an organized description of what was carried out during this research period, and finally certain considerations.

\section{Integrating Videos in EFL class}

The last decade's advancements in education have presented a growing trend towards introducing video-based activities in EFL classrooms worldwide. It is said that for various years educators have been constantly working on videos as input; likewise, generating their own as part of encouraging students to do so as well. As a result of this sort of implementation, nowadays the process of education in some countries has a powerful emphasis on mobile and learner-center approach (Cowie \& Sakui, 2020). According to Kolås et al. (2012) there is a considerable interest in applying short videos for educational purposes called "EPE (easy production educational)" which could be developed by following four main stages: 1) The preparation phase, 2) The learning activities, 3) Follow up work and, 4) Assessment. However, the main challenge faced by many EFL teachers is the selection of appropriate videos or create them to show learners social interaction and at the same time provide them an opportunity to experiment film entertainment (Sun, 2020). 
One of the most significant current methods in favor of education regards on Eclectic method which institutes a sensible view for addressing interaction in language learning. Results from earlier studies demonstrate a strong and consistent association between video-based activities and EFL education (Yorio, 1987). For instance, a broader perspective about videos in education has been adopted by Lee \& Lo (2014) who suggest that learners should follow five stages during activities (experience, understand, practice, reflect, and apply) as part of a sequenced learning process. A considerable amount of literature has been analyzed on Video Based Learning (VBL), these studies have demonstrated that many useful activities could be deployed by using quizzes, embedded questions or exercises of video comprehension at any stage of videos aimed at developing classroom learning goals (Kolas, 2015).

\section{Video based activities}

The prevalence of video-based activities in EFL is increasing at a great number of possibilities of delivering information through an interactive and dynamic video resources. Therefore, a study of VBL developed to measure learners`achievement after conducting an experiment of combining video-based learning environment without specific interaction and the time devoted to fulfilling those activities have not shown significance results on terms of learning acquisition. However, learner's exposure to embedded multiple-choice questions have demonstrated considerable positive effects in language learning achievement since this helpful tool is aligned to discover the relationship between the time spending on complete an assigned activity and learning achievement (Vural, 2013).

According to Rice et al. (2019) questions embedded in videos for educational purposes shine a new light on the effectiveness of VBL through an important assimilation of the information conducted in videos. For instance, at this stage of learning practical session by introducing segments for measuring understanding on what has been shown or presented in videos maintain an active learner's role as well as a higher level of human brain and senses' activation. The experimental work of including animated videos in EFL provides originality of the lesson, enhance relevant pedagogy, and build learners execution of creativity skills in the learning process (Gurvitch \& Lund, 2014). On the contrary, debates continue about to find out the most powerful video strategies to avoid that learner misunderstands certain aspects displayed in videos which might be fictional or even a lie, those perspectives should be analyzed in detail to guide students to eradicate stereotypes arguing that videos have been developed to transmit multiple emotions, humor, drama, sarcasm, and many factors totally flexible on video scenes (Sun, 2020). 


\section{Videos as an input process}

Teaching English through authentic videos can play a fundamental role in addressing the issue of understanding. Evidence suggests that videos are among the most popular resources for teaching due to their unique characteristics that may lead to a successful language encounter by replacing traditional classroom based and teacher-centered approaches (Yousef et al., 2014). There is a growing body of literature that recognizes YouTube as the most influential data base platform for sharing content, context and language for educational purposes, this well-known site is visited massively every day (Morat et al., 2017). Besides, the performance of activities embedded in videos could be widely open to relieve the experience of learning repeatedly depending on the level of complexity and task extension (Berk, 2009).

There have been several studies involving videos as part of education that have reported some drawbacks in utilizing video in the classroom. For instance, the debate about criteria for selecting appropriate videos has gained fresh prominence with many arguing that teachers must align their video material to fulfill learner's needs and curricula goals promoting effective learning acquisition and creativity development that supports activities (Sunubi \& Utary, 2020). However, there has been disagreement on the criteria for defining the most suitable video-based structure for creating content opposed to mere watching video due to the fact that the act of generating video involves different skills, technical equipment usage, design and edition, and final product distribution, otherwise the process will be useless in terms of pre-production, production, and post-production stages (Snelson, 2018).

\section{Language assimilation through videos}

The main strengths of VBL represent a comprehensive examination of the whole benefits of language assimilation through videos. For instance, videos provide the opportunity to visualize how the language works in a specific situation and at the same time they might show information in detail which attracts learner`s attention (Yousef et al., 2014). On the one hand, the relevance of video in education is clearly supported by numerous studies that show vast comprehension of language content since they allow learners to receive immediate feedback, which results in higher language assimilation and engagement (Rice et al., 2019). On the other hand, the application of video in EFL classroom takes up so much time, for this reason, time should be controlled by the teacher to set the right amount of guidance to fully perform each task avoiding unexpected issues (Sun, 2020).

Further investigation conducted by Berk (2009) regarding the effects of videos on individual's understanding determines that learners after being exposed to different sort of video based activities demonstrated twenty potential outcomes to consider as follows: 1) Grab students' attention 2)Focus students' concentration 3) Generate interest in class 
4) Create a sense of anticipation 5) Energize or relax students for learning exercise 6) Draw on students' imagination 7) Improve attitudes toward content and learning 8) Build a connection with other students and instructor 9) Increase memory of content 10) Increase understanding 11)Foster creativity 12) Stimulate the flow of ideas 13) Foster deeper learning 14) Provide an opportunity for freedom of expression 15) Serve as a vehicle for collaboration 16) Inspire and motivate students 17) Make learning fun 18) Set an appropriate mood or tone; 19) Decrease anxiety and tension on scary topics; and 20). Create memorable visual images.

\section{Video comprehension quizzes}

In-video quizzes highlight the potential usefulness of interaction at certain segments of video-based activities. A natural progression of this interaction section during a video quiz is to analyze how learners comprehend the topic being discussed and notice the learners' behavior while doing the intervention of quiz in order to make some modifications on individual's requirements to improve on teaching content over time (Cummins et al., 2015). There are a couple of platforms such as Educaplay and Playposit that can be used to develop targeted video quiz interventions aimed at measure the level of understanding of a topic. Huang et al. (2014) make an interesting contribution mentioning several interactive types of questions (i.e., multiple choice quiz, true-false questions, and gap filled quiz, yes/no questions, and WH-questions) which should be elaborated by using understandable grammatical structures and derived from simple to complex ones.

\section{Integrating a test inside the video}

Recently, video test application proved an important study field in the EFL educator's community. Along with this educational need, there is an increasing trend to assess video test not only for making interactive the learning process during the presentation of the content but also for testing periodically students' understanding. This study also mentioned some key relevant factor to be distinguished in video-quiz: The test is designed to appear at certain section of the video, and be answered the embedded questions, during normal video playback, with the video pausing for the student to answer the question. The test should also be taken at suitable times within the video content to pretend interactive discussion between speaker and individual learner. After sending a reply, the test automatically should provide feedback to the learner on their answer prior to the video continuing, in this manner, it could be simulated a simple dialogic interaction (Cummins et al., 2015, p 2). 


\section{Video as an output process}

The process of generating videos for academic purposes demonstrates an association between knowledge development on any content area and technological learning at the same time. For instance, when learners are assigned to create a video for EFL class as part of an illustrative representation of a topic, they become active producers of the language rather than passive consumers of media information (Snelson, 2018). In addition, a study conducted by Sunubi \& Utary (2020), demonstrates that students' expertise on video creation promotes positive attitudinal factors towards language learning aimed at meeting curricula goals. According to Mathew \& Alidmat (2013) the proper environment for learning a language should be modified to stimulate learner's creativity, foster values for a meaningful learning, and increase motivation among classmates. Furthermore, producing videos integrate self-paced language practice due to the fact that learners might find a challenge to overcome which constitutes a source of free language experience (Vural, 2013).

\section{Teaching colloquialism with authentic video}

Outside the language classroom, learners might encounter certain drawbacks when exchanging language due to the cultural bound represented on informal language and special features of the language identified in worldwide communication (Nurain, 2020). In consideration of interaction exposed in real life contexts, the use of informal language constitutes the most transcendental part of language learning and similarly conceived as a long-life process. Needless to say, that nowadays, technology has opened and ample opportunity to be in constant language learning through the unlimited input readily available (Bahrani \& Sim, 2012). Undoubtedly, videos created by native speakers are considered beneficial for L2 learners since they express the essence of the language in its real contexts where learners came across slangs, idiomatic expressions, intonation and stress, dialects, and reduced speech (Frumuselu et al., 2015).

\section{Sitcoms for understanding colloquial language}

Watching sitcoms as part of informal language exposure in the EFL classroom determines an important plus to boost learners` motivations and entertainment on account of humor and the representation of cultural background involved in the plot (Lima \& Senefonte, 2020). According to Sun (2016), the introduction of comedy in accordance with teaching requirements provides a great variety of linguistic features to be analyzed in class. In line with it, the application of communication analysis based on American sitcoms (i.e., The Simpsons, Fiends, Two and a half man, The Big Bang Theory) in EFL classrooms approximate learners to natural language exposure and offer them the opportunity to increase conversation abilities and oral proficiency through verbal and nonverbal interaction of native speakers (Nurain, 2020). All in all, the value of learning colloquial 
language through sitcoms is not only a matter of acquiring certain cultural understanding but also integrate a pedagogical tool within the learning curricula in EFL classroom.

\section{Language and culture into the classroom}

Learning a language is not only a matter of acquiring proficiency on speech or grammar but also adopting a vast understanding of cultural heritage across worldwide countries (Nurain, 2020). The ability to efficiently enhance communication in a L2 language is crucial to adapt to the host culture when living abroad since people tend to feel immersed, motivated, and confidence to exchange language within or across numerous social situations (Gallagher, 2013). However, when nonnative speakers are exposed to real language conversations, there could be an overgeneralization of grammar rules and syntax for learning a language rather than a fluent speech as it is delivered by natives who focus on communication about multiple topics (Lee, 2016). In addition, social media triggers conversational models produced in daily speech where learners set their basis to acculturate and springboard language proficiency on real life conversation events (Nurain, 2020).

\section{Methodology}

The research design utilized data from a twenty multiple choice pretest and posttest's questionnaire. The current study was conducted with two courses of high school from the following specialties Baccalaureate of Science and Technical Baccalaureate at the Eloy Alfaro Educational Unit. The study employed 25 participants who received a treatment intervention (13 female and 12 male) and 25 participants who belonged to the control group (11 male 14 female). The purpose of this study set out to respond this work hypothesis: Do Video based activities promote understanding of colloquialisms broadcasted on sitcoms? Moreover, the depth will be settled as descriptive and explanatory analysis encompassed with socio-educational modality. Therefore, the information provided in this paper was supported in a bibliographical-documentary and field research which was determined by the behavior of participants during treatment intervention.

To achieve this, the study was carried out during a four-week intervention period distributed into twelve sessions of thirty minutes, every lesson allowed the introduction of a video with embedded multiple-choice questionnaires programmed to work out in an interactive session on Microsoft Teams platform. Taking into consideration the activities based on videos, participants had to analyze, understand, and practice the examples of colloquial language presented in class. In addition to this, participants received immediate feedback for each example learned in class. Basically, the feedback explanation covered the relationship between the understanding of colloquial expressions in real contexts and pragmatics. 
The videos focused on presenting five examples of colloquial expressions broadcasted on popular American TV series about multiple situations that occurs spontaneously in daily life (i.e., at home, in public places, informal gatherings, eventual conversations etc.). In line with it, there were incorporated embedded activities such as multiple-choice questionnaire and free-text interventions within the same video. These video-based activities were broadcasted in two different ways, such as: videos as input and video as output (based on PlayPosit and Educaplay video quiz platforms). In contrast, in order to generate video as output, Padlet and Flipgrid platforms were implemented to achieve language production.

The easiness of the accessibility to these platforms was a factor to be considered during this study as well as the level of vocabulary and degree of difficultness of exercises to be taught using current trends in language teaching. The methodological approach applied in this study is a mixed methodology based on quantitative and qualitative data. The primary data obtained for this study is a twenty multiple choice questionnaire developed and distributed online using Google forms, the questionnaire was customized in detail to make sure that each subject did not receive the same order of questions. Besides, participants responded the tests anonymously. Moreover, the link of the pretest and posttest questionnaire that measure the understanding on colloquial language was assessed appropriately before and after the intervention segment. The time assigned to complete the tests was 30 minutes scheduled to be done during class time from $07 \mathrm{~h} 10 \mathrm{am}$ to $07 \mathrm{~h} 40$.

In addition, a survey was conducted among participants to analyze the level of treatment satisfaction. Basically, it was implemented a liker scale survey using Google forms and then shared remotely among subjects through a link. Furthermore, preliminary data entry was analyzed using due to the free access, variable manipulation, and compatibility, subsequently, this information was categorized and codified according to a sophisticated analyses and data interpretation regarding the effect of video-based activities upon understanding colloquial language. Finally, the results and discussion were analyzed meticulously considering descriptive statistics t-test (Şahin \& Aybek, 2019).

\section{Results}

The effects of video-based activities on informal language understanding are aimed at answering the research question: Do Video based activities promote understanding of colloquialisms broadcasted on sitcoms? Students` pretest and posttest results after being exposed to colloquialisms broadcasted on American sitcoms applying different learning strategies using embedded video activities have exposed a considerable increment on their final scores. Needless to mention that at beginning of the intervention proposal, students from both groups were not previously taught on this content. The treatment process involved a conglomerated of techniques meticulous designed to promote an 
enjoyable learning atmosphere. Based on students' preferences, the treatment combined multiple choice questions, gap filling statements, matching vocabulary, voice and video recording, memes creation, and oral presentations addressed the content to take the final vocabulary test on colloquial language. This test was analyzed by experts on this topic and piloting with similar groups from other institutions in order to note mistakes or possible changes to be included. The statistically significant difference in pretest and posttest on colloquial language was proven by Shapiro wilk test where the overall $(\mathrm{M}=$ $8.000, \mathrm{SE}=0.542$, $\mathrm{p}$-value $=<.001$ ) was less than the critical $\mathrm{p}$-value. In line with it, it can be concluded that implementing videos as part of language teaching, especially on colloquial language, promotes favorable outcomes.

Table 1

Summary of intervention results

\begin{tabular}{|c|c|c|c|c|c|c|}
\hline & \multicolumn{6}{|l|}{ Descriptive } \\
\hline & & $\mathbf{N}$ & Mean & Median & SD & SE \\
\hline POSTTEST & SCORE IG & 25 & 16.16 & 16.00 & 2.10 & 0.419 \\
\hline POSTEST & SCORE IG & 25 & 8.16 & 8.00 & 1.65 & 0.330 \\
\hline PRETEST & SCORE IG & 25 & 11.08 & 11.00 & 4.90 & 0,98 \\
\hline PRETEST & SCORE IG & 25 & 11.72 & 11.00 & 5.08 & 1.016 \\
\hline
\end{tabular}

After doing this important phase, the results of final questionnaire on colloquial language between intervention group (IG) and control group (CG) pretest scores and IG and CG posttest scores are represented in table 1, figure 2 and figure 3.

\section{Table 2}

Pretest and posttest scores

\begin{tabular}{|c|c|c|c|c|c|c|c|c|c|c|c|c|c|c|}
\hline \multirow[t]{2}{*}{$\begin{array}{l}\text { Paired } \\
\text { Sample T- } \\
\text { Test }\end{array}$} & & & & & & & & & $\begin{array}{r}95 \\
\text { Conf } \\
\text { Int }\end{array}$ & & & & $\begin{array}{c}\mathbf{9 5 \%} \\
\text { Confidence } \\
\text { Interval } \\
\end{array}$ & \\
\hline & & & & statistic & df & p & $\begin{array}{l}\text { Mean } \\
\text { difference }\end{array}$ & $\begin{array}{l}\text { SE } \\
\text { difference }\end{array}$ & lower & uper & & $\begin{array}{l}\text { Effect } \\
\text { size }\end{array}$ & lower & uper \\
\hline Postest & SCORE IG & SCORECG & student's t & 14.771 & 24.0 & $<.001$ & 8.000 & 0.542 & 6.88 & 9.12 & Cohen's d & 2.954 & 2.030 & 3.866 \\
\hline Pretest & SCORE IG & SCORECG & student's t & -0.602 & 24.0 & 0.553 & -0.640 & 1.063 & -2.83 & 1.55 & Cohen's d & -0.120 & -0.513 & 0.274 \\
\hline
\end{tabular}

Source: Şahin \& Aybek (2019)

It is quite important to highlight whether the differences in the gathered data results are statistically significant, the pair samples T-Test were applied to explore the differences between pretest and posttest scores from the control and interventionist group. The principal findings are determined as follows: on the one hand, the scores obtained without any intervention in both groups shows $(\mathrm{M}=-0.640, \mathrm{SE}=1.063$, $\mathrm{p}$-value $=0,553)$, what it is understood with this data that participants did not demonstrate vast knowledge on colloquial language. 


\section{Figure 1}

Interventionist group posttest scores

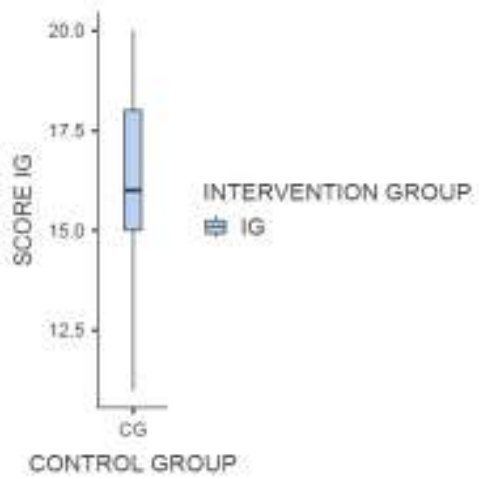

On the other hand, after applying four-week intervention treatment the scores particularly demonstrate a significant dissimilarity between interventionist and controlled groups' posttest scores synthetized as follows $(\mathrm{M}=8.000, \mathrm{SE}=0.542$, $\mathrm{p}$-value $=<.001)$. Consequently, and based on the information of the final test on colloquial languages, it could be pointed out that applying video based activities to understand colloquial language entail noteworthy evidence of acquiring effective achievement in terms of comprehension and acquisition of informal language among teenagers. Likewise, the results demonstrate certain tendencies to learn idioms that are related to technology and social media faster than the ones used for replacing phrases related to day-to-day context.

Figure 2

Control group scores

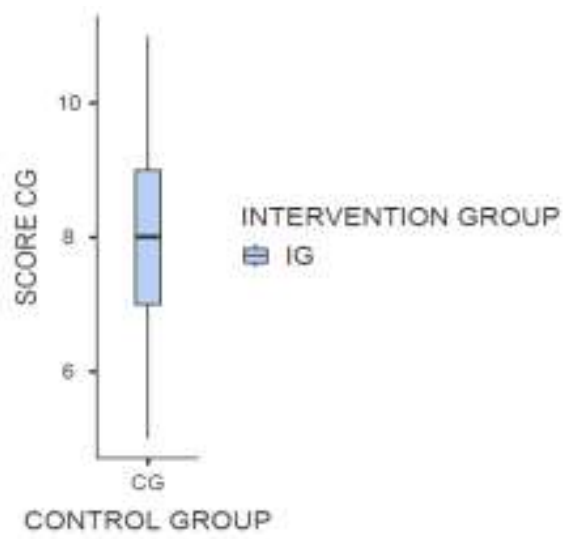

\section{Discussion}

The results of pretest and posttest showed a significant difference on participants' scores. Besides, subjects demonstrated positive attitude towards learning colloquial language through the application of video based activities. In the pre-activities before playing the 
videos, a very short explanation of cultural background of colloquial language was presented as a general overview. In addition, at this stage, the presenter explained the instructions to be followed during and after watching the assigned video. With and without intervention students received feedback on this topic to reinforce the content aimed in the class. A descriptive statistically significant difference could be detected after the application of 12 intervention sessions (IG vs. CG $<0.001$ ).

Table 3

Shapiro Wilk analysis

\begin{tabular}{lcccc}
\hline Descriptive & & & & \\
& POSTEST & & PRETEST & \\
N & & SCORE & SCORE & \multicolumn{1}{l}{ SCORE } \\
N & Score IG & CG & IG & CG \\
Mean & 25 & 25 & 25 & 25 \\
Median & 16.2 & 8.16 & 11.1 & 11.7 \\
Mode & 16.0 & 8.00 & 11.0 & 11.0 \\
Sum & 15.0 & 8.00 & 7.00 & 19.0 \\
Standard Deviation & 404 & 204 & 277 & 293 \\
Variance & 2.10 & 1.65 & 4.90 & 5.08 \\
Range & 4.39 & 2.72 & 24.0 & 25.8 \\
Minimum & 9.00 & 6.00 & 18.0 & 14.0 \\
Maximum & 11.0 & 5.00 & 2.00 & 6.00 \\
Skewness & 20.0 & 11.0 & 20.0 & 20.0 \\
Std.error Skewness & -0.437 & -0.216 & 0.227 & 0.447 \\
Kurtosis & 0.464 & 0.464 & 0.464 & 0.464 \\
Std. Error Kurtosis & 0.291 & -0.401 & -0.756 & -1.34 \\
Shapiro-Wilk W & 0.902 & 0.955 & 0.967 & 0.865 \\
Shapiro-Wilk p & 0.968 & 0.955 & 0.967 & 0.865 \\
\hline
\end{tabular}

Source: Şahin \& Aybek (2019)

Based on this study results, it can be concluded that those findings support the assumption that video based activities promote understanding on colloquial language among teenagers as well as increase the participant's attitudes towards learning informal language. On the contrary, the CG participants have not showed a significant improvement on colloquial language, it seems to be that subjects are not completely interesting on this topic due to the limitless resources used to teach them. Basically, the context where some of the participants received the treatment sessions advocated difficultness to establish a high quality of resources to experiment online platforms and visual resources to better comprehend the language used in informal conversations carried out by natives in real English speaking countries. 
Overall, watching authentic videos and performing embedded video activities embodies a powerful and meaningful teaching-learning trend to be executed in EFL classrooms due to the easiness to monitor students own pace development. It is also advisable to name the platforms that contributed to carry out this study (e.g., PlayPosit, Educaplay video quiz, Flipgrid, and Padlet). There is no doubt that future investigation on this field will determine broader perspectives on how to manage and make useful these sorts of authentic resources to get students involved in an active and dynamic learning development. For that reason, there is a vast list of repositories that exposed similar studies to take advantages from them to generate future opportunities to guide students to a globalized language encounter. By this means, educators from all levels in public or private schools should focus their attention on encouraging pupils to start getting immersed in this important topic since the language they possible acquired will give them a plus to sound more natural.

\section{Limitations while using videos based activities}

During the intervention process by using video based activities to understand colloquialisms broadcasted on sitcoms among teenagers, there were certain obstacles such as: difficultness of lexical comprehension, accessibility to the video generator`s platforms due to the unavailability of the Internet connection in the participant's communities. Besides, it results important to mention certain drawbacks that at the beginning of the study generating inconveniences. First, students were not familiar with the language in use, it means that every idiom expressed on dialogues originates doubts. In order to overcome this common cultural background issue, researchers should focus their attention towards preparing students on managing online platforms, it would be suitable to schedule lessons tailor -made students 'needs.

\section{Conclusions}

- The application of videos based activities for understanding colloquial languages has been deemed. As a matter of fact, the introduction of embedded activities using videos and clips of popular American sitcoms have shown variety of English language that goes beyond the standard one. Basically, there is a wide range of language exposure through differentiation on speech. It means, that languages do not vary only due to the fact of social interaction but also owing internal factors, like language competences. Establishing meaningful conversations in day-to-day social interaction requires vast knowledge on grammar and vocabulary, cultural background aimed at employing the language in each context. Institution cannot ignore this perspective. In order to conclude this study, it is necessary to bring back the research question, and the objectives previously settled.

- Do Video based activities promote understanding of colloquialisms broadcasted on sitcoms? As the language guidelines for educators in Ecuador advocates the 
implementation of CLIL within the teaching practices of foreign languages, it results absolutely important to exposed students to real language through authentic materials, like sitcoms. The didactic proposal considered to conduct this study, video based activities were developed to teach informal aspects of English and promote language awareness by watching sitcom genre.

- The first aim is addressed to determine innovative approaches for helping students to understand informal English conversation which can be used in class or serve as a starting point for educators in order to generate their own didactic material. The biggest challenge of this study was to join all language features broadcasted on American sitcoms and current trends on EFL teaching. It is worth mentioning that this paper is restricted to literature review and a didactic proposal, and an evaluation of treatment between an interventionist group and controlled group. Hence, after concluding this study, it could be noted that students neither receive enough content on colloquialisms nor authentic language which leaded to different misunderstanding factors like cultural background, literal translation of idioms and slangs, and deficit for producing language.

- The second aim was focused on the creation of a handbook with video based activities and strategies to teach colloquial language among teenagers. This procedure was developed taking into consideration students 'level, needs, and age as part of an integral informal language involvement. After treatment application, it can also be concluded that students require more expertise on this teaching content since information is currently updating and vocabulary is even getting more advanced through the time. The results of this study were illustrated to the educational community right after finishing it in order to help teachers to linked informal language into the classroom.

\section{Bibliographic References}

Bahrani, T., \& Sim, T. S. (2012). Informal language learning setting: Technology or social interaction? Turkish Online Journal of Educational Technology, 11(2), 142149.

Bajrami, L., \& Ismaili, M. (2016). The Role of Video Materials in EFL Classrooms. Procedia - Social and Behavioral Sciences, 232(April), 502-506. https://doi.org/10.1016/j.sbspro.2016.10.068

Berk, R. (2009). Multimedia teaching with video clips: TV, movies, YouTube, and mtvU in the college classroom. International Journal of Technology in Teaching \& Learning, 5(1), 1-21.

Bravo, E., Amante, B., Simo, P., Enache, M., \& Fernandez, V. (2011). Video as a new 
teaching tool to increase student motivation. 2011 IEEE Global Engineering Education Conference, EDUCON 2011, May 2014, 638-642. https://doi.org/10.1109/EDUCON.2011.5773205

Cowie, N., \& Sakui, K. (2020). Teacher and student-created videos in English language teaching. ELT Journal, 75(January). https://doi.org/10.1093/elt/ccaa054

Cummins, S., Beresford, A. R., \& Rice, A. (2015). Investigating Engagement with InVideo Quiz Questions in a Programming Course. 1382(c), 1-10. https://doi.org/10.1109/TLT.2015.2444374

Frumuselu, A. D., De Maeyer, S., Donche, V., \& Colon Plana, M. del M. G. (2015). Television series inside the EFL classroom: Bridging the gap between teaching and learning informal language through subtitles. Linguistics and Education, 32, 107117. https://doi.org/10.1016/j.linged.2015.10.001

Gallagher, H. C. (2013). Willingness to communicate and cross-cultural adaptation: L2 communication and acculturative stress as transaction. Applied Linguistics, 34(1), 53-73. https://doi.org/10.1093/applin/ams023

Gurvitch, R., \& Lund, J. (2014). Animated Video Clips. 8-18. http://eric.ed.gov/?id=EJ1032650

Huang, Y., Tseng, Y., Sun, Y. S., \& Chen, M. C. (2014). TEDQuiz: Automatic Quiz Generation for TED Talks Video Clips to Assess Listening Comprehension. https://doi.org/10.1109/ICALT.2014.105

Kolas, L. (2015). Application of interactive videos in education. 2015 International Conference on Information Technology Based Higher Education and Training, ITHET 2015. https://doi.org/10.1109/ITHET.2015.7218037

Kolås, L., Munkvold, R., \& Nordseth, H. (2012). Evaluation of EPE videos in different phases of a learning process. IADIS International Conference on Cognition and Exploratory Learning in Digital Age, CELDA 2012, Celda, 99-106.

Lee, E. J. E. (2016). International and American students' perceptions of informal English conversations. Journal of International Students, 6(1), 14-34. https://doi.org/10.32674/jis.v6i1.394

Lee, V., \& Lo, A. (2014). From theory to practice: Teaching management using films through deductive and inductive processes. International Journal of Management Education, 12(1), 44-54. https://doi.org/10.1016/j.ijme.2013.05.001

Lima, A. R. D. C., \& Senefonte, F. H. R. (2020). Informal English through sitcoms. BELT 
- Brazilian English Language Teaching Journal, 11(1), e36650. https://doi.org/10.15448/2178-3640.2020.1.36650

Mathew, N. G., \& Alidmat, A. O. H. (2013). A Study on the Usefulness of Audio-Visual Aids in EFL Classroom: Implications for Effective Instruction. International Journal of Higher Education, 2(2), 86-92. https://doi.org/10.5430/ijhe.v2n2p86

Metruk, R. (2018). The effects of watching authentic English videos with and without subtitles on listening and reading skills of EFL learners. Eurasia Journal of Mathematics, Science and Technology Education, 14(6), 2545-2553. https://doi.org/10.29333/ejmste/90088

Morat, B. N., Shaari, A., Abidin, M. J. Z., \& Abdullah, A. (2017). YouTube within ESL classroom: Exploring an instructor's and her learners' experiences concerning the authenticity of language and technology use. Malaysian Journal of Learning and Instruction, 2017(Special Issue), 173-196. https://doi.org/10.32890/mjli.2017.7802

Nurain Mudawe, O. M. (2020). Enhancing EFL Students' Cultural Awareness through Friends Sitcom. International Journal of Applied Linguistics and English Literature, 9(4), 76. https://doi.org/10.7575/aiac.ijalel.v.9n.4p.76

Park, Y., \& Jung, E. (2016). Exploring the Use of Video-clips for Motivation Building in a Secondary School EFL Setting. English Language Teaching, 9(10), 81. https://doi.org/10.5539/elt.v9n10p81

Plonsky, L., \& Ziegler, N. (2016). The CALL-SLA interface: Insights from a secondorder synthesis. Language Learning and Technology, 20(2), 17-37.

Rice, P., Rice, P., Beeson, P., \& Blackmore-wright, J. (2019). Evaluating the Impact of a Quiz Question within an Educational Video. 522-532.

Şahin, M., \& Aybek, E. (2019). Jamovi: An Easy to Use Statistical Software for the Social Scientists. International Journal of Assessment Tools in Education, 6(4), 670-692. https://doi.org/10.21449/ijate.661803

Snelson, C. (2018). Video production in content-area pedagogy: a scoping study of the research literature. Learning, Media and Technology, 43(3), 294-306. https://doi.org/10.1080/17439884.2018.1504788

Sun, L. (2020). Students' Attitudes and Perspectives Towards Using Videos in Technology Assisted English Class. Advances in Educational Technology and Psychology, 4(1), 1-11. https://doi.org/10.23977/aetp.2020.41001

Sun, Q. (2016). The Applicability in Selection of American sitcoms as Materials for 
Teaching English listening and speaking. Icsste, 323-326. https://doi.org/10.2991/icsste-16.2016.60

Sunubi, A. H., \& Utary, R. (2020). Video-Based Learning (VBL): An Implementation on Advanced Learners of English Class. ELITE JOURNAL, 197-206. http://elitejournal.org/index.php/ELITE/article/view/44

Vural, O. F. (2013). The Impact of a Question-Embedded Video-Based Learning Tool on E-Learning, Educational Sciences: Theory and Practice, 2013. Educational Sciences: Theory \& Practice, 13(2), 1315-1323.

Yousef, A. M. F., Chatti, M. A., \& Schroeder, U. (2014). The state of video-based learning: A review and future perspectives. International Journal on Advances in Life Sciences, 6(3-4), 122-135.

Yorio, C. (1987). Building Multiple Bridges: Eclecticism in Language Teaching. TESL Canada Journal, 5(1), 91-100. https://doi.org/10.18806/tesl.v5i1.519

\section{LCiencia}


El artículo que se publica es de exclusiva responsabilidad de los autores y no necesariamente reflejan el pensamiento de la Revista Ciencia Digital.

\section{LCiencia}

El artículo queda en propiedad de la revista y, por tanto, su publicación parcial y/o total en otro medio tiene que ser autorizado por el director de la Revista Ciencia Digital.

\section{lationdễ catálogo}
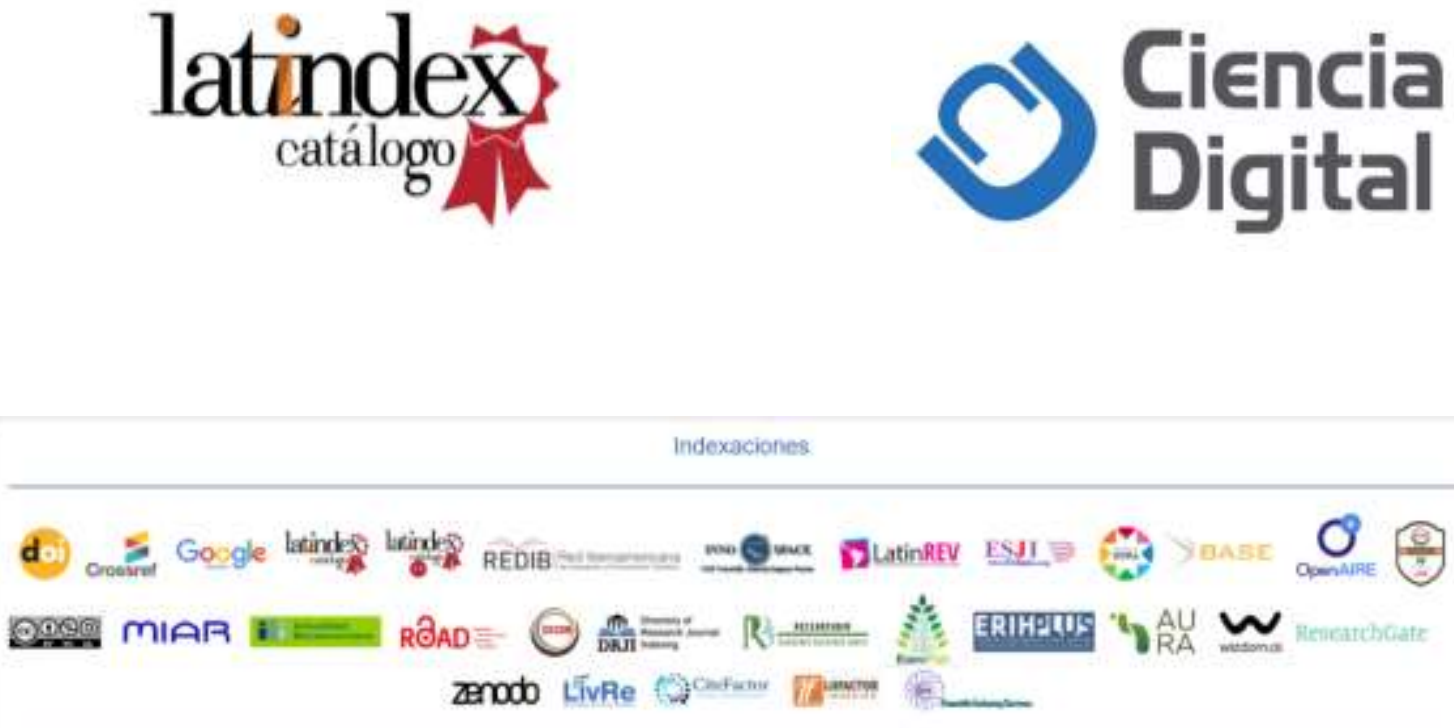